\title{
LEARNING ATTITUDE: STUDENT PERCEPTION ON PANDEMIC COVID-19 IN BANDUNG, INDONESIA
}

\author{
Iwan Sidharta \\ Sekolah Tinggi Ilmu Ekonomi, Pasundan, Bandung, Indonesia. \\ E-mail: i_sidh@stiepas.ac.id
}

\begin{abstract}
At the time of the COVID-19 pandemic in Indonesia, several learning changes occur in higher education, such as the implementation of online learning. This change is a concrete step for the government to overcome the spread of the COVID-19 virus in Indonesia. However, the change of learning to online has several obstacles in its implementation where both students and teachers are still not used to online learning. This study investigates student knowledge about covid 19 and its implications for student learning attitudes and behavior. An online survey using google forms to students of undergraduate and postgraduate programs at the School of Economics, Pasundan, Bandung, Indonesia, has as many as 247 students. The researchers used a nonparametric structural equation modeling approach to identify the effect of student knowledge about COVID-19 on attitudes and learning behavior. The study results identified that student knowledge had a positive influence on student attitudes and negatively affected learning behavior. This condition indicates that the increasing threat of covid 19, which students know, will be more positive in their actions; however, their learning behavior will decrease. For this reason, it is necessary to take comprehensive steps by the parties concerned to implement effective policies in reducing the impact of covid 19 to improve student learning behavior. The novelty of this research is that no research identifies a model of the influence of knowledge regarding the impact of covid 19 on student behavior and learning behavior in Indonesia.
\end{abstract}

Keywords: knowledge, attitudes, learning behavior, students, covid 19.

\section{INTRODUCTION}

At the time of the Covid-19 pandemic in Indonesia, it impacted psychological changes in people's behavior. The impact of the pandemic has caused the government to impose several rules that can cause the spread of the COVID-19 virus in Indonesia. Policies are taken by the Indonesian government, such as imposing restrictions on community activities at a certain level to suppress community mobility. (www.covid19.go.id) In the education sector, several changes cause education actors to adapt to the rules set by the government, such as the implementation of online learning. (Sahu, 2020) 
The situation where educators and students are not familiar with online learning causes psychological changes in teaching and learning habits. (Dhawan, 2020) Both teachers and students who are not familiar with online learning cause behavioral changes to adapt to online learning technology. (Rony \& Awal, 2019) Most educators and students who do not understand and do not even know about online learning cause emotional anxiety, harming the continuity of a good education. (Tabish, 2020)

Limited information regarding the impact and causes of the COVID-19 virus has confused taking steps to adopt online learning, both by policymakers and implementers and students. (Mukhtar, Javed, Arooj \& Sethi, 2020) For this reason, it is necessary to have a mapping of information regarding the impact of the covid-19 virus in carrying out learning well without neglecting good quality. The mapping can prepare policymakers and education sector implementers to make online learning plans that follow government regulations. Changes that occur can result in student emotional instability, which can have an impact on learning outcomes. (Perera \& DiGiacomo, 2013)

Preliminary research indicates that to suppress the spread of the COVID-19 virus, necessary to take several steps following health protocols, such as using masks, washing hands with antiseptic, maintaining distance between individuals, and avoiding crowds. (www.covid19.go.id) In general, this step is self-quarantining from contact with other individuals who are feared to have the Covid-19 virus. However, this step is only a temporary solution; it cannot solve the problem as a whole. It is necessary to take comprehensive steps that can control the overall cause of the COVID-19 virus.

From the side of education actors, both teachers and students who adopt online learning need to know related information about the impact of the virus and the behavior needed in carrying out online learning. (Dhawan, 2020; Mukhtar, Javed, Arooj \& Sethi, 2020) The implementation of online learning requires both educators and students to adapt to the use of information technology such as adapted information systems. (Keis, Grab, Schneider \& chsner, 2017) The information system recommended by policymakers is to use online learning applications familiar to both teachers and students, such as Google Classroom for online learning media and zoom, google meet, WhatsApp for media. Face to face online.

The use of this information system, when viewed from the hardware side, requires devices that can facilitate the information media used, while from the network side, what type of internet channel can support online learning. (Shenoy, Mahendra \& Vijay, 2020) From the end-user side, both educators and students need learning user-friendly, easy to use, and helpful. Boy \& Sidharta (2015), who researched information systems, revealed several aspects that can provide quality information, such as easy use, timely, accurate, and helpful information for users.

In connection with the critical role of online learning media, it is necessary to provide information about the behavior of students regarding the covid-19 pandemic so that steps can take to solve problems due to the lack of information about the behavior of students on the impact of changes in behavior, implementing adaptation of new habits that the government has set. (Reimers, Schleicher, Saavedra \& Tuominen, 2020) Online learning behavior requires support for independent learning by developing self-potential. This 
condition is related to behavior in the development of students who need support from teachers and education. (Huang, 2020)

Currently, there is no research on covid 19 that affects learning attitudes and behavior in Indonesia. To bridge the research gap, the researchers investigated predictive research models to identify the effect of knowledge about COVID-19 on attitudes and implications for learning behavior.

\section{RESEARCH METHODS}

To predict the research model developed, the researcher uses an online survey approach which is analyzed quantitatively. At the time of the COVID-19 pandemic, the learning process carries out online. The sampling process used a google form aimed at undergraduate and postgraduate students at the Pasundan School of Economics, Bandung, Indonesia. Questionnaire distribution involves academic staff responsible for distributing questionnaire links through WhatsApp media in each study program. The collection of the questionnaires lasted for 3 (three) weeks, with a total of 247 students who filled out the questionnaire completely.

The research instrument base on a literature review that has researched knowledge and learning behavior construct. Researchers reviewed several studies that became the basis for the preparation of knowledge instruments, such as research conducted by Aggarwal \& Panat (2013); Al-Shamiri, AlShalawi, AlJumah, AlHarthi, AlAli \& AlHarthi (2018); Khasawneh, Humeidan, Alsulaiman, Bloukh, Ramadan, Al-Shatanawi \& Kheirallah (2020); Alharbi, Shono, Alballaa \& Aloufi (2019); ALNohair, Mahmud, ALShehri, ALShuqayran \& ALBatanouni (2020) and Almofada, Alherbisch, Almuhraj, Almeshary, Alrabiah, Al Saffan \& Baseer (2020) and Huynh, Nguyen, Vo \& Pham (2020).

As for learning behavior, researchers developed from Worrell, Vandiver \& Watkins (2001). There are 12 (twelve) instruments to measure knowledge, 6 (six) instruments to measure attitudes, and 8 (eight) instruments to measure learning behavior so that the total instrument is 26 instruments. Each instrument was measured using a 7-point Liker scale from strongly disagree to strongly agree.

The results of the instrument testing indicated that several research instruments were invalid and reliable so that only 5 (five) instruments were used to measure knowledge, 4 (four) instruments to measure attitudes, and 4 (four) instruments to measure learning behavior. Valid and reliable instruments will be present in the appendix. The results of the outer loading instrument have a value $>0.5$, which can see in table 1 below:

Table 1. Outer loading instrument

\begin{tabular}{|l|c|c|c|}
\hline Instrument & AP & KN & LB \\
\hline A2 & 0,760 & & \\
\hline A3 & 0,860 & & \\
\hline A4 & 0,644 & & \\
\hline
\end{tabular}




\begin{tabular}{|l|l|l|l|}
\hline A6 & 0,558 & & \\
\hline K10 & & 0,739 & \\
\hline K11 & & 0,777 & \\
\hline K12 & & 0,822 & \\
\hline K4 & & 0,578 & \\
\hline K8 & & 0,589 & \\
\hline LB4 & & & 0,530 \\
\hline LB5 & & & 0,691 \\
\hline LB6 & & & 0,873 \\
\hline LB7 & & & 0,797 \\
\hline
\end{tabular}

After testing the outer model, the researchers conducted further testing as described in the results and discussion. In analyzing the respondents' results, the researcher used a nonparametric structural equation modeling approach. This approach is more relevant in predicting the initial model, which is in the development stage.

\section{RESULTS AND DISCUSSION}

Descriptive results regarding the characteristics of respondents who are undergraduate and postgraduate students at the School of Economics, Pasundan, Bandung Indonesia, consisting of $66 \%$ male and $44 \%$ female, while the age of the respondents is dominated by students from undergraduate programs as much as $57.9 \%$ as shown see in Figure 1 below:

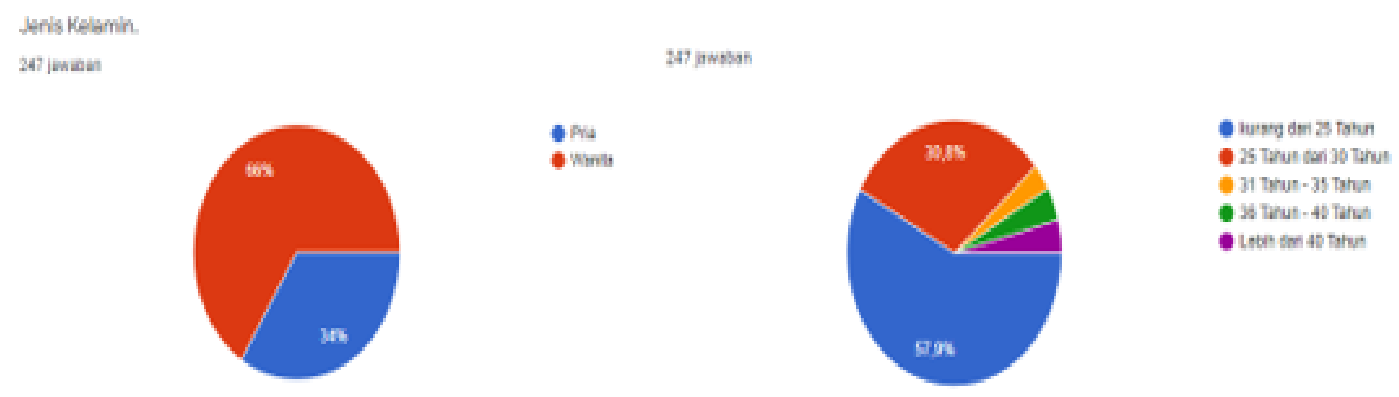

Figure 1. Descriptive results of respondents

Before further analysis, the researchers tested the instrument's validity and reliability that developed, referring to several previous studies. The test results are shown in Table 2 below: 
Table 2 . The results of the test of construct validity and reliability

\begin{tabular}{|l|c|c|c|c|}
\hline Construct & Cron. Alpha & rho_A & Comp. Rel & AVE \\
\hline AP & 0,676 & 0,746 & 0,803 & 0,510 \\
\hline KN & 0,747 & 0,778 & 0,831 & 0,501 \\
\hline LB & 0,730 & 0,804 & 0,819 & 0,539 \\
\hline
\end{tabular}

Note: $\mathrm{AP}=$ Attitude, $\mathrm{KN}=$ Knowledge, $\mathrm{LB}=$ Learning behavior

Table 2 above shows that all study constructs have CA values $>0.6$ with $\mathrm{rA}>0.7, \mathrm{CR}$ $>0.8$ and AVE > 0.5. Overall, the research construct test showed an adequate value, and further testing could carry out. This result can be seen further by testing discriminant validity with Fornell-Lacker criteria as shown in table 3 below;

Table 3. Results of Discriminant Validity Fornell-Larcker Criterion

\begin{tabular}{|l|c|c|c|}
\hline Construct & AP & KN & LB \\
\hline AP & 0,714 & & \\
\hline KN & 0,681 & 0,708 & \\
\hline LB & $-0,177$ & $-0,203$ & 0,734 \\
\hline
\end{tabular}

In table 3, discriminant validity results indicate that all constructs meet the criteria set by Fornell-Larcker, where each construct has a correlation value between constructs that are greater than the other constructs. Finally, prediction level testing can see in table 4, where the results of the p-value of each construct are present.

Table 4. Research construct prediction test

\begin{tabular}{|l|c|c|c|c|}
\hline \multicolumn{1}{|c|}{ Path } & Path value & St.Dev & P-values & Conclusions \\
\hline AP -> LB & $-0,072$ & 0,087 & 0,038 & Accept \\
\hline KN -> AP & 0,681 & 0,057 & 0,000 & Accept \\
\hline KN -> LB & $-0,203$ & 0,067 & 0,002 & Accept \\
\hline & \multicolumn{2}{|c|}{ R Square } & \multicolumn{2}{c|}{0,462} \\
\hline AP & \multicolumn{2}{|c|}{0,464} & \multicolumn{2}{c|}{0,036} \\
\hline LB & \multicolumn{2}{|c|}{0,044} &
\end{tabular}

Table 4 above shows that the proposed research construct is acceptable where the significance value of the p-value is below 0.005 . Thus, the influence of student attitudes is 0.462 or $46.2 \%$, while the influence of learning behavior is $0.036 \%$ or $3.6 \%$. The table above shows that student attitudes towards learning behavior have a path value of -0.072 , student knowledge of student attitudes has a path value of 0.681 , and student knowledge of learning behavior has a path value of -0.203 . The calculation results can describe as shown in Figure 2 below. 


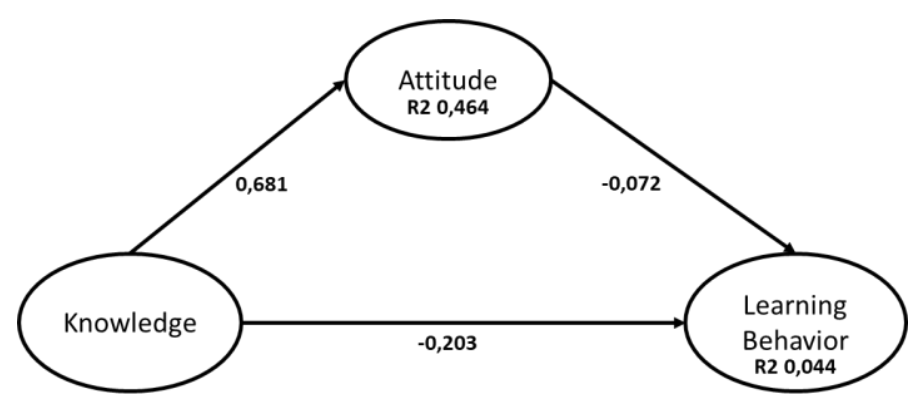

Figure 2. Results of paths between constructs

The study results indicate that there is a positive influence on students' knowledge about covid 19 on their attitudes. This situation can be used as an early indication that students' increasing knowledge about COVID-19 will have a positive effect on their attitudes. This attitude showed by behavior that can accept the situation that the current situation is unfavorable and needs an understanding of covid 19 so that students can overcome obstacles that occur during a pandemic. Furthermore, with knowledge about covid 19, students can anticipate and estimate what steps they must take to deal with this covid 19 pandemic. The results of this study are in line with research conducted by Ataş \& Yildirim (2020) and Zayapragassarazan (2020), which illustrates that having adequate knowledge about the COVID-19 pandemic can make individual behavior better in overcoming the challenges caused by the COVID-19 pandemic.

Student knowledge about covid 19 has a negative influence on learning behavior and student attitudes towards learning behavior. This result is an early indication that the better students' knowledge of the impact of the COVID-19 pandemic will impact decreasing student learning behavior. This situation can cause by the fear of students that the impact of the COVID-19 pandemic can be bad for their learning development. (Qiu, Shen, Zhao, Wang, Xie \& Xu, 2020) Students feel that currently, they are not ready to face the impact of covid 19 if it lasts for a long time. For this reason, the participation of various related parties must provide a sense of security to students so that their learning conditions are better, such as providing internet quotas, providing convenience in providing academic services. They provide training or insight on using information technology in online learning and various aspects that can alleviate the online student learning load.

Psychologically, students feel that the COVID-19 pandemic is a phenomenon of health symptoms that they have never faced. The level of readiness for psychological impacts causes an increase in student anxiety which has implications for the less conducive learning conditions felt by students. (Adnan \& Anwar, 2020) The study results indicate that psychologically students are not ready to face the dangers caused by the pandemic covid 19. (Wang, Pan, Wan, Tan, Xu, Ho \& Ho, 2020) Need steps to provide psychological guidance for students to reduce the level of anxiety and the level of fear so that student learning conditions can run in a conducive manner. (Petrides, 2019). 
The results of this study are in line with research conducted by Gupta, Singh \& Kumar (2017), which proves that the level of anxiety and the level of fear experienced by individuals will result in the emergence of negative emotions.

\section{CONCLUSION}

The study results can be an initial indication of students' knowledge and attitudes and their impact on learning behavior during the covid 19 pandemic. The developed instrument has an adequate level of validity and reliability and can be used as a reference to measure students' cognitive aspects and learning behavior in abnormal situations. The prediction results indicate that aspects of knowledge about covid 19 significantly influence both student attitudes and learning behavior. Knowledge about covid has a positive impact on attitudes in overcoming obstacles to the covid 19 pandemics. On the other hand, knowledge about covid 19 has a negative effect on student learning behavior and student attitudes. This situation indicates that the higher the severity of the COVID19 pandemic will further reduce student learning behavior. For this reason, it is necessary to take comprehensive steps taken by all relevant parties to reduce the impact of Covid-19 to improve student learning behavior, such as providing counseling guidance to reduce the level of anxiety and fear of students over the impact of the COVID-19 pandemic.

This research has a novelty where research is still rare that identifies the influence of the cognitive aspects of students during the COVID-19 pandemic on student learning behavior in Indonesia. However, there are still some weaknesses in this study where the sample used is only students who study in economics, not covering other fields. In addition, this study only predicts the model, so there is a need for explanatory testing to generalize the study results. For further research, the researcher suggests that the new model can test using a broader sample and several factors that influence student learning behavior.

\section{REFERENCES}

Adnan, M., \& Anwar, K. (2020). Online Learning amid the COVID-19 Pandemic: Students' Perspectives. Online Submission, 2(1), 45-51.

Aggarwal, A., \& Panat, S. R. (2013). Knowledge, attitude, and behavior in managing patients with HIV/AIDS among a group of Indian dental students. Journal of Dental Education, 77(9), 1209-1217.

Alharbi, G., Shono, N., Alballaa, L., \& Aloufi, A. (2019). Knowledge, attitude and compliance of infection control guidelines among dental faculty members and students in KSU. BMC Oral Health, 19(1), 1-8. https://doi.org/10.1186/s12903-018-0706-0

Almofada, S. K., Alherbisch, R. J., Almuhraj, N. A., Almeshary, B. N., Alrabiah, B., Al

Saffan, A., \& Baseer, M. A. (2020). Knowledge, attitudes, and practices toward 
COVID-19 in a Saudi Arabian population: a cross-sectional study. Cureus, 12(6). doi: 10.7759/cureus.8905

ALNohair, S. F., Mahmud, I., ALShehri, F., ALShuqayran, R., \& ALBatanouni, M. (2020). Knowledge, Attitudes, and Practices of Medical Interns Toward COVID-19 in Saudi Arabia: A Cross-Sectional Survey, April-May 2020.

Al-Shamiri, H. M., AlShalawi, F. E., AlJumah, T. M., AlHarthi, M. M., AlAli, E. M., \& AlHarthi, H. M. (2018). Knowledge, attitude and practice of hepatitis B virus infection among dental students and interns in Saudi Arabia. Journal of clinical and experimental dentistry, 10(1), e54. doi: 10.4317/jced.54418

Ataş, O., \& Yildirim, T. T. (2020). Evaluation of knowledge, attitudes, and clinical education of dental students about COVID-19 pandemic. PeerJ, 8, e9575.

Bao, W. (2020). COVID-19 and online teaching in higher education: A case study of Peking University. Human Behavior and Emerging Technologies, 2(2), 113-115.

Dhawan, S. (2020). Online learning: A panacea in the time of COVID-19 crisis. Journal of Educational Technology Systems, 49(1), 5-22.

Gupta, R., Singh, N., \& Kumar, R. (2017). Longitudinal predictive validity of emotional intelligence on first year medical students perceived stress. BMC medical education, 17(1), 1-6.

Huang, J. (2020). Successes and Challenges: Online Teaching and Learning of Chemistry in Higher Education in China in the Time of COVID-19. Journal of Chemical Education, 97(9), 2810-2814. https://doi.org/10.1021/acs.jchemed.0c00671

Huynh, G., Nguyen, T. N. H., Vo, K. N., \& Pham, L. A. (2020). Knowledge and attitude toward COVID-19 among healthcare workers at District 2 Hospital, Ho Chi Minh City. Asian Pacific Journal of Tropical Medicine, 13(6), 260. Available from: https://www.apjtm.org/text.asp?2020/13/6/260/280396

Khasawneh, A. I., Humeidan, A. A., Alsulaiman, J. W., Bloukh, S., Ramadan, M., AlShatanawi, T. N., ... \& Kheirallah, K. A. (2020). Medical students and COVID-19: knowledge, attitudes, and precautionary measures. A descriptive study from Jordan. Frontiers in public health, 8, 253. https://doi.org/10.3389/fpubh.2020.00253

Keis, O., Grab, C., Schneider, A., \& Öchsner, W. (2017). Online or face-to-face instruction? A qualitative study on the electrocardiogram course at the University of Ulm to examine why students choose a particular format. BMC medical education, 17(1), 1-8. doi:10.1186/s12909-017-1053-6.

Mukhtar, K., Javed, K., Arooj, M., \& Sethi, A. (2020). Advantages, Limitations and Recommendations for online learning during COVID-19 pandemic era. Pakistan journal of medical sciences, 36(COVID19-S4), S27-S31. doi: 10.12669/pjms.36. COVID19-S4.2785

Petrides, K. V. (2019). A conceptual application of Psychobionomy to the field of personality and individual differences. Personality and Individual Differences, 147, 135-143. https://doi.org/10.1016/j.paid.2019.04.018

Perera, H. N., \& DiGiacomo, M. (2013). The relationship of trait emotional intelligence with academic performance: A meta-analytic review. Learning and individual differences, 28, 20-33. https://doi.org/10.1016/j.lindif.2013.08.002 
Reimers, F., Schleicher, A., Saavedra, J., \& Tuominen, S. (2020). Supporting the continuation of teaching and learning during the COVID-19 Pandemic. Oecd, 1(1), 138.

Rony, H. A. Z., \& Awal, S. T. (2019). University teachers' Training on online teachinglearning using online platform during Covid-19: a case study. Bangladesh Educ. $J, 18(2), 57-64$.

Sahu, P. (2020). Closure of universities due to coronavirus disease 2019 (COVID-19): impact on education and mental health of students and academic staff. Cureus, 12(4), e7541. doi: 10.7759/cureus.7541

Shenoy, V., Mahendra, S., \& Vijay, N. (2020). COVID 19 lockdown technology adaption, teaching, learning, students engagement and faculty experience. Mukt Shabd Journal, 9(4), 698-702.

Suzanto, B., \& Sidharta, I. (2015). Pengukuran end-user computing satisfaction atas penggunaan sistem informasi akademik. Jurnal Ekonomi, Bisnis \& Entrepreneurship, 9(1), 16-28.

Tabish, S. A. (2020). COVID-19 pandemic: Emerging perspectives and future trends. Journal of public health research, 9(1), 1786.doi: 10.4081/jphr.2020.1786

Worrell, F. C., Vandiver, B. J., \& Watkins, M. W. (2001). Construct validity of the Learning Behavior Scale with an independent sample of students. Psychology in the Schools, 38(3), 207-215.

Zayapragassarazan, Z. (2020). COVID-19: Strategies for Engaging Remote Learners in Medical Education. F1000Research, 9(273), 1-18. DOI: 10.7490/f1000research.1117835.1

\section{Appendix}

\begin{tabular}{|l|l|}
\hline \multicolumn{2}{|l|}{ Instrument (Indonesian Version) } \\
\hline Knowledge & $\begin{array}{l}\text { Mencegah penularan COVID-19 dengan cara menghindari } \\
\text { pergi ke tempat keramaian dan menghindari pertemuan. }\end{array}$ \\
\hline K10 & $\begin{array}{l}\text { Test, Trace and Isolate (TTI) adalah cara efektif untuk } \\
\text { mengurangi penyebaran COVID-19. }\end{array}$ \\
\hline K12 & $\begin{array}{l}\text { Orang yang melakukan kontak dengan seseorang yang } \\
\text { terinfeksi virus COVID-19 harus segera diisolasi di tempat } \\
\text { yang tepat. Secara umum periode pengamatan selama 14 hari. }\end{array}$ \\
\hline K4 & $\begin{array}{l}\text { Tidak semua orang dengan COVID-19 akan berkembang } \\
\text { menjadi kasus yang parah. Mereka yang lanjut usia memiliki } \\
\text { penyakit kronis, dan obesitas lebih cenderung menjadi kasus } \\
\text { yang parah. }\end{array}$ \\
\hline K8 & $\begin{array}{l}\text { Orang biasa bisa memakai masker medis umum untuk } \\
\text { mencegah penularan virus COVID-19. }\end{array}$ \\
\hline
\end{tabular}




\begin{tabular}{|l|l|}
\hline Attitude & $\begin{array}{l}\text { Menurut Saudara/i COVID-19 merupakan ancaman bagi } \\
\text { komunitas Saudara/i }\end{array}$ \\
\hline A3 & $\begin{array}{l}\text { Saya pikir isolasi akan meningkatkan kesejahteraan masyarakat } \\
\text { secara keseluruhan dalam hal mengendalikan situasi pandemi } \\
\text { COVID-19 }\end{array}$ \\
\hline A4 & $\begin{array}{l}\text { Belakangan ini, apakah Anda pernah mengenakan masker saat } \\
\text { keluar rumah }\end{array}$ \\
\hline A6 & $\begin{array}{l}\text { Saudara/i mengikuti strategi yang direkomendasikan oleh } \\
\text { pemerintah (misalnya Kementerian Kesehatan) untuk } \\
\text { mencegah infeksi dan penyebaran COVID-19 }\end{array}$ \\
\hline Learning Behavior & $\begin{array}{l}\text { Saudara/i mengalami kesulitan dalam melakukan dua tugas } \\
\text { secara bersamaan }\end{array}$ \\
\hline LB4 & $\begin{array}{l}\text { Saudara/i mengalami kesulitan dalam melakukan perhitungan } \\
\text { dalam proses belajar }\end{array}$ \\
\hline LB5 & $\begin{array}{l}\text { Saudara/i mengalami kesulitan dalam mengingat informasi } \\
\text { terkini } \\
\text { Saudara/i mengalami kesulitan dalam mengingat informasi } \\
\text { lama }\end{array}$ \\
\hline LB7 &
\end{tabular}

